\title{
A Experiência do Espectador: Recepção, Audiência ou Emancipação?
}

\section{The Spectator's Experience: Reception, Audience or Emancipation?}

\section{La Experiencia del Espectador: Recepción, Audiencia o la Emancipación?}

\author{
Fabio Montalvão Soares* \\ Universidade Federal do Rio de Janeiro - UFRJ, Rio de Janeiro, Rio de Janeiro, Brasil
}

\section{Virgínia Kastrup**}

Universidade Federal do Rio de Janeiro - UFRJ, Rio de Janeiro, Rio de Janeiro, Brasil

\begin{abstract}
RESUMO
O artigo propõe uma discussão teórica sobre o estatuto da experiência do espectador no cinema, baseando-se no conceito de emancipação intelectual formulado por Jacques Rancière (2008). Partindo dos estudos sobre recepção, realiza uma crítica ao problema relativo à passividade do público, enfatizando a perspectiva do espectador emancipado. Ao destacar que a discussão sobre a experiência se limita, no âmbito desses estudos, à análise do comportamento do público, inferida a partir de índices de audiência, o texto atenta para o fato de não se considerar a dimensão processual e corporificada (Varela, Thompson, \& Rosch, 1991), sendo o comportamento algo da ordem dos efeitos do que da experiência em si mesma. Conclui ainda que os estudos sobre recepção não dão conta do problema da experiência do expectador de modo satisfatório. Neste sentido, a emancipação surge como possibilidade de afirmação de uma concepção corporificada da experiência, que deverá ser objeto de investigação em estudos empíricos futuros.
\end{abstract}

Palavras chave: espectador, experiência, emancipação, cinema.

\begin{abstract}
The article proposes a discussion on the statute of the spectator's experience in cinema, based on the concept of intellectual emancipation formulated by Jacques Rancière (2008). From of the reception studies, was made a critique of problem of the public passivity, emphasizing the perspective of the emancipated spectator. To emphasize that the discussion about the experience is limited, in the context of these studies, to an public behavior analysis, inferred from audience ratings, the text draws attention to the fact that their procedural and embodied dimension (Varela, Thompson, \& Rosch, 1991 ) is not considered, being the behavior, something of the order of effects, than of the experience itself. It also concludes that the studies on reception are not enough to address the problem of experience of viewer satisfactorily. Consequently, the emancipation arises as a possibility for
\end{abstract}


research a conception of embodied experience, which should be the subject of research in future empirical studies.

Keywords: spectator, experience, emancipation, cinema.

\section{RESUMEN}

El artículo propone una discusión sobre el estatuto de la experiencia del espectador del cine, basando en el concepto de la emancipación intelectual formulado por Jacques Rancière (2008). A partir de los estudios de recepción, él hace una crítica al problema de la pasividad del público, enfatizando la perspectiva del espectador emancipado. Destacando que la discusión acerca del experiencia es limitada, en este tipo de estudios, en el análisis de comportamiento del público inferidas a partir de los índices de audiencia, el texto llama la atención sobre la falta de consideración de su dimensión procesal y corporal (Varela, Thompson, \& Rosch, 1991), teniendo en cuenta el comportamiento como algo del orden de los efectos en lugar de la propia experiencia. También concluye que los estudios sobre la recepción no son suficientes por abordar el problema de la experiencia del espectador satisfactoriamente. En consecuencia, la emancipación aparece como una posibilidad para la investigación de una experiencia encarnada, que será objeto de investigación en futuros estudios empíricos.

Palabras clave: espectador, experiencia, emancipación, el cine.

\section{I ntrodução: da Recepção à espectatorialidade}

O termo espectador costuma ser atribuído, no campo das pesquisas sobre o audiovisual e produção de subjetividades, à pessoa que interage com os dispositivos midiáticos e artísticos os mais variados. Ele designa, por exemplo, aquele que ordinariamente assiste a um programa televisivo, visita um museu ou uma galeria de arte, joga videogames e se conecta as redes sociais, assiste a uma peça de teatro ou a uma obra audiovisual em uma sala de cinema. Poderíamos supor, levando em conta seu uso atual, referir-se ao conjunto de indivíduos que, por meio dos mais variados modos, interagem com o universo das imagens produzidas no contexto de diferentes dispositivos artísticos e tecnológicos.

Atualmente, no terreno do audiovisual e especificamente no cinema, os estudos sobre o espectador vêm dando destaque a seu papel ativo na interação com as obras, o que tem gerado um amplo debate em relação ao estatuto de sua atividade/passividade. De acordo com Stam (2000), a espectatorialidade diz respeito ao campo dedicado aos estudos e pesquisas voltadas ao espectador. Em se tratando de teoria do cinema "não seria totalmente correto falar em nascimento do espectador, uma vez que ela sempre dedicou atenção à questão da espectatorialidade" (Stam, 2000, p. 255). A análise da espectatorialidade investiga os agenciamentos e tensionamentos produzidos no plano das relações entre os dispositivos, os discursos e o contexto histórico que moldam o espectador e a própria obra cinematográfica. Para estudiosos como Mascarello (2001; 2004), 
historicamente as pesquisas sobre espectatorialidade são herdeiras dos estudos sobre recepção, tradicionalmente concentrados no campo da televisão. A recepção é entendida, de acordo com Orozco (2001), como um processo mediado por diversos meios e fontes e contextualizado material, cognitiva e emocionalmente, desdobrandose numa complexidade de contextos e cenários, nos quais se incluem as "estratégias e negociações dos sujeitos com as referências midiáticas das quais resultam apropriações variadas que vão, desde a mera reprodução até a resistência e sua contestação" (Orozco, 2001, p.23).

Para Mascarello (2004), os estudos sobre recepção cinematográfica são fortemente influenciados pela lógica do que denomina como determinismo textual. Este postula a redução da relação cinema popular/espectador à condição de um evento determinado especificamente pelo texto fílmico, em detrimento do contexto histórico e do espectador concreto, considerando-o, neste sentido, totalmente passivo. Herdeira de uma tradição inspirada na crítica de Brecht (1964), nos estudos sobre semiologia de Barthes (1964) e posteriormente, na interpretação de cunho psicanalítico de Metz, (1980) a principal ideia dessa vertente é a de que a estrutura narrativa das obras cinematográficas segue as premissas do discurso textual, que atua aí como modelo de referência. Cabe salientar que o determinismo textual foi a concepção dominante nos estudos sobre recepção, surgida no contexto do Modernismo Político ${ }^{1}$, movimento que ganhou notoriedade no final da década de 60 e durante a de 70 . Gomes (2005) aponta o aspecto de passividade como característica marcante e presente, tanto no plano da obra, quanto no do espectador. A autora destaca que "as análises textuais explicam o objeto gerando interpretações a partir dele (...). Estas análises retiram o texto (e a recepção, por consequência) da história, ou seja, removem o texto de seu contexto" (Gomes, 2005, p. 1143). Nelas o espectador é compreendido "como uma entidade abstrata e passiva às suas leituras e prazeres com o texto fílmico dominante, sendo condenada como instrumento de um 'posicionamento subjetivo' no interior da ideologia capitalista" (Mascarello, 2004, p. 92). Embora possamos vislumbrar o reconhecimento de certa visão ativa do público relativa às "leituras e prazeres", tal condição se restringe somente à interpretação dos elementos definidos a priori pela estrutura e texto fílmico. Ou seja, eles seriam sempre definidos pela obra, sendo logicamente pensados e proporcionados por ela. Sobre esse ponto, Stam (2000) afirma que "nos anos 70, a teoria psicanalisava os prazeres da situação cinematográfica como tal, para logo afirmar que, nos anos 80 e 90 , os analistas tornaram-se mais interessados pelas formas socialmente diferenciadas de espectatorialidade" (Stam, 2000, p. 229). 
Os autores citados destacam também o movimento inglês da ScreenTheory ${ }^{2}$, caracterizado por um discurso crítico, mas de continuidade à tradição estruturalista vigente, no qual o paradigma continuaria a ser o do espetáculo que cria o espectador, e não o contrário. Nele, o objeto fílmico é criado e submetido ao mesmo tempo à narrativa como determinante do que é projetado na tela, sendo este, por sua vez, mascarado pelo realismo aparente do conteúdo comunicado. Entretanto, embora de cunho mais flexível em relação ao lugar ocupado pelo espectador (considerado agora em sua dimensão perceptiva e mesmo histórica) as discussões propostas pelo movimento da Screen-Theory ainda mantêm uma visão estritamente passiva deste. Segundo Mascarello:

De modo geral, o fato é que as considerações sobre a importância do contexto histórico de recepção sobre a relação texto/espectador vêm aparecer somente na condição de ressalva ou apêndice à investigação central, que permanece sendo sempre a das estruturas textuais como posicionadoras do sujeito-espectador (Mascarello, 2001, p. 25).

O autor menciona ainda o surgimento de um novo movimento de tradição anglo-americana durante a década de 80 , denominado como Estudos Cuturalistas de Espectatorialidade Cinematográfica. Como observa Stam (2000), esses estudos investem na disseminação de seus valores na cultura, por meio de uma ampla gama de dispositivos, onde os textos estão inseridos em uma matriz social e produzem consequências sobre o mundo. "Os estudos culturais chamam a atenção para as condições sociais e institucionais no interior das quais o sentido é produzido e recebido" (Stam, 2000, p. 250). Trata-se, por conseguinte, de uma visível oposição ao determinismo textual como definidor a priori de todos os sentidos possíveis da obra sem, porém, alterar substancialmente o paradigma de uma suposta passividade do espectador.

Mascarello (2004), também afirma, a partir da leitura da obra de Turner (2000), um deslocamento da perspectiva da análise textual em direção a uma visão mais aberta e de aceitação das interferências do público no processo. O fato curioso é que tal movimento é operado a partir dos estudos sobre as audiências cinematográficas. Este afirma que:

$\mathrm{Na}$ medida em que os estudos culturais deslocaram-se dos textos para as audiências, e desta forma para as estruturas sociais que situam os indivíduos como audiências, também os estudos de cinema voltaram a examinar seus contextos culturais e econômicos constitutivos (Turner 2000, citado por Mascarello, 2004, p. 95). 
Orozco (2001) destaca a importância da audiência nos estudos sobre recepção. O termo se refere não a um índice relativo a uma mera atividade receptiva por parte do público, mas a uma série de ações mediadas por uma diversidade de vetores sociais, culturais e históricos. Neste momento é interessante observar que os estudos sobre as audiências (tal como destacamos acima nos trabalhos de Mascarello e Orozco) evidenciam um dado importante em relação às leituras sobre a espectatorialidade. Esses estudos mostravam de modo paradoxal uma postura inversa por parte do público às expectativas dos intelectuais e produtores das obras, isto é, sobre o que os segundos teorizavam em relação aos primeiros. Se não havia, por exemplo, uma rejeição explícita das obras (indicada em termos de comportamento do público inferido por índices de audiência), no mínimo existia um hiato entre aquilo que o corpus teórico pensava, a partir do discurso textual e dos seus produtos, e a experiência concreta dos espectadores. As tecnologias empregadas na produção poderiam não ser, assim, plenamente eficazes na cooptação do público; fato este que potencialmente poderia ser indicado pelas audiências como instrumento de contato com essa realidade. Sobre este ponto, descreve Escotesguy (2006):

No final dos anos 80, observa-se, contudo, que o desenvolvimento da pesquisa sobre as audiências manifesta-se muito mais centrado no receptor e no seu contexto. Assim, o texto deixa de ser um princípio estruturante na produção de sentido e a investigação passa a concentrar-se muito mais na compreensão das determinações contextuais da recepção (Escotesguy, 2006, p. 08).

Entendemos a importância e a valorização dos estudos sobre a audiência, no sentido de uma crítica ao modelo textualista vigente e como um elemento importante no tocante ao conhecimento da realidade do público. Numa perspectiva atual, Stam (2000) afirma o espectador como mais ativo e crítico, e não como objeto passivo de interpelação por parte dos dispositivos audiovisuais. Neste sentido, ao apresentarmos esta breve explanação acerca dos estudos sobre a espectatorialidade como oriunda dos estudos sobre recepção, não podemos deixar de destacar alguns pontos importantes que nos remetem a tomada de alguns posicionamentos estratégicos em nossa discussão.

Em relação ao próprio campo da recepção, acompanhando a perspectiva trazida por Stam (2000) e pelos demais autores até aqui citados, podemos constatar que o tema do espectador se encontra vinculado a um debate em torno de um suposto status de passividade ou atividade. Algumas abordagens assumem uma visão do 
espectador como agente passivo, tais como o determinismo textual. Outras entendem que o público comparece de forma mais efetiva no processo, como no caso da Screen-Theory e na perspectiva culturalista. Consideramos ainda, que não seja clara na abordagem desses autores, uma divisão nítida entre o que seria da ordem da recepção e o que seria concernente ao espectador de cinema propriamente dito, o que termina por manter a crença numa equivalência entre essas duas instâncias.

Jacks $(2008 ; 2014)$ afirma, em seu mapeamento sobre as pesquisas que tratam do tema da recepção no Brasil, que poucos trabalhos analisam o receptor e o gênero midiático televisivo no intuito de perceber a relação entre eles, desconsiderando os aspectos textuais e os da produção midiática: "a presença da pesquisa de recepção ainda se dá de forma muito tímida" (Jacks, 2014, p.11). Em relação à discussão sobre a recepção no âmbito do cinema, as referências são ainda mais escassas; Jacks (2008) dedica um único subcapítulo à recepção no cinema, mantendo-se um cenário semelhante na pesquisa de 2014. Em relação à obra de Mascarello (2001; 2004) (único pesquisador mencionado a tratar especificamente do tema), cita a autora:

Apesar do pioneirismo do estudo e de sua relevância e contribuição em termos do debate teórico, o limite desse trabalho é que o autor não chega a propor uma teoria para pensar a relação do público com o cinema, como anuncia, chegando a recomendações de ordem genérica a partir da crítica às teorias vigentes (J acks, 2008, p. 280).

Deste modo, consideramos importante sublinhar que as atividades do espectador são muito mais abrangentes do que a recepção de imagens propriamente dita. De acordo com Stam (2000):

Texto, dispositivo, discurso e história, em suma, encontram-se todos em jogo e em movimento. Nem o texto, nem o espectador são entidades estáticas, pré-constituídas; os espectadores moldam a experiência cinematográfica e são por ela moldados, em um processo dialógico infinito (Stam, 2000, p. 256).

Desse modo, podemos estabelecer pelo menos dois modos de abordar a questão. O primeiro coloca que, se no tocante ao público, há espaço para pensarmos em termos de recepção, não poderíamos pensar que se trate somente de recepção imagens que constituem o texto fílmico, mas de uma diversidade de vetores heterogêneos, de relações de poder que se intercruzam e constituem a experiência audiovisual propriamente dita. Não temos que considerar a recepção 
associada a uma suposta passividade, pois o espectador pode, por exemplo, mobilizar uma série de recursos e ações diversas, no sentido de receber aquilo que é emitido. O segundo modo considera que, se existe recepção, poderíamos supor, sem nenhuma contradição, que exista também emissão por parte do espectador. Emissão de leituras diversas, de opiniões, de afetos, de posicionamentos construídos a partir de apropriações dos materiais audiovisuais, de múltiplas trocas de saber, de modos de subjetivação constituídos numa intensa produção polifônica e coletiva. Um deslocamento desta ordem recoloca o problema em uma dimensão mais ampla, pois se é verdade que há emissão de imagens e de discursos por parte dos dispositivos, não se pode deixar de pensar que haja também por parte do público.

O espectador se apropria, tanto da obra exibida, quanto dos discursos que a circundam. Isso se torna visível, por exemplo, na assimilação, por parte do público, dos discursos que operam a produção de uma obra, ou daqueles produzidos sobre seu produto final e a partir dele; além, é claro, de o espectador contribuir diretamente na proposição destes mesmos discursos. O espectador é afetado pela obra em diversas dimensões. Busca informações sobre sua produção, lê críticas, se posiciona contra ou a favor delas a partir de suas percepções, conversa com outros espectadores, estabelece análises e reflexões através das impressões e afetos produzidos na relação com a obra e na incorporação dos discursos a ela relacionados. Tais atitudes transbordam e escapam a qualquer determinismo implícito numa dicotomia atividade/ passividade, entendidos estes como lugares fixos, ou de uma perspectiva diretiva e submetida à narrativa e a discursividade de um texto fílmico. Escapa igualmente a qualquer tentativa de captura promovida por meio dos recursos tecnológicos, no sentido de previsão das reações e comportamentos.

A análise da espectatorialidade deve, portanto, investigar as lacunas e tensões entre os diferentes níveis, as diversas formas por meio das quais o texto, o dispositivo, a história e o discurso constroem o espectador, e as formas como também o espectador, como sujeito-interlocutor, molda esse encontro (Stam, 2000, p. 257).

Se o diretor ou produtor deseja, por exemplo, contar uma história a partir da exploração das tecnologias de edição, técnicas de narratividade e através de supostos saberes sobre o espectador, conduzindo o público didaticamente a um objetivo específico por meio delas, nos parece claro que existe neste processo uma contradição. Esta se expressa no fato de se acreditar que a experiência do espectador seja totalmente manipulada por essas tecnologias e que ele simplesmente reaja passivamente a elas. Porém, "a história do 
cinema, nesse sentido, é não apenas a história dos filmes e dos cineastas, mas também a história dos sucessivos sentidos que o público tem atribuído ao cinema" (Stam 2000, p. 257). O público, além de simplesmente seguir os caminhos pré-estabelecidos pelos produtores/artistas, pode ultrapassá-los e produzir suas próprias leituras e significações em relação ao que assiste. Talvez seja este o interesse inicial de uma atenção especial à audiência, pois ela indicaria, de certo modo, esse movimento peculiar. Ela de fato pode apontar os movimentos divergentes dos espectadores em relação às expectativas dos diretores e produtores, que pretensamente se colocam na posição de entender os modos de funcionamento do público.

Outro fator importante na discussão da relação espectador/ audiência, é o de que ela expressa muito menos a posição real ou a experiência do público e muito mais um índice geral e submetido aos ditames do mercado. O fato de se assistir ou não a um filme (ou a um programa televisivo) é efeito de uma multiplicidade de fatores, muito além de questões especificamente ligadas ao mercado e a estes índices, consequentemente, ultrapassando seus limites. Em se tratando do assunto, Escotesguy e Jacks (2005) destacam que maioria das pesquisas sobre essa temática eram implementadas através de métodos quantitativos, configurando-se como exclusivamente voltadas para o mercado publicitário. O espectador era tratado como consumidor, prevalecendo fatores como poder aquisitivo, práticas e hábitos de consumo. Sob esse ângulo, ponderam:

É importante dizer também que, de modo geral, a expressão audiência e por sua vez, pesquisa de audiência, está associada àquelas investigações com fins mercadológicos e, sobretudo, de caráter quantitativo. Isto está de tal forma incrustado nessa problemática, que falar em audiência é sinônimo de índice de audiência e, quase sempre, este último passa a chamar-se ibope. (Escotesguy \& Jacks, 2005, p. 110).

Até o presente momento, destacamos o posicionamento crítico desses autores frente aos estudos sobre recepção e a questão da audiência, percebendo a não delimitação de uma diferença explícita entre as noções de recepção e espectatorialidade; tampouco o que concerne especificamente a cada uma delas. No entanto, os estudos sobre a audiência nos abrem um problema significativo no que se refere à espectatorialidade, pois eles afirmam, a princípio, a possibilidade de melhor conhecer a experiência do público. Propomos então a pergunta: em que consiste o plano da experiência do espectador? Qual a sua natureza? 


\section{De que experiência falamos?}

A experiência não deve ser entendida apenas como experiência passada, ou seja, um somatório cumulativo das vivencias de um sujeito pré-existente, produzida por sua relação com uma diversidade de objetos igualmente pré-estabelecidos num mundo a priori. O que buscamos é investigar a experiência do espectador em sua abertura ao presente. Para Varela, Thompson e Rosch (1991) as concepções usuais de experiência esbarram sempre na manutenção de uma visão dicotômica entre sujeito e objeto, ignorando, tanto o aspecto consensual da experiência, quanto sua dimensão corporificada. De acordo com estes autores, devemos levar em conta que existe uma circularidade fundamental, na qual não podemos separar o sujeito do conhecimento do mundo conhecido. E acrescentam: "Não existe nenhum conhecedor/observador abstrato de uma experiência que esteja separado da própria experiência" (Varela et al., 1991, p. 53). Afirma-se assim, a codependência entre a experiência e o sujeito da experiência, entre o sujeito do conhecimento e o mundo conhecido. Sujeito, mundo e os objetos que o compõem não são simplesmente instâncias definidas apriori que se colocam em relação arbitrariamente. A experiência se dá num agenciamento codependente, ou antes, num coengendramento. Ela surge simultaneamente ao sujeito da experiência, moldando-se permanente e reciprocamente, uma vez que "todas as coisas se encontram vazias de qualquer natureza intrínseca independente. Isto poderá soar como uma afirmação abstrata, mas tem implicações de longo alcance para a experiência" (Varela et al., 1991, p. 290).

É preciso sublinhar que a experiência do espectador, no âmbito dos estudos sobre a espectatorialidade, é reduzida ao problema do comportamento do público, das suas ações e reações aos dispositivos, considerando-os de forma polarizada em relação à dimensão espectatorial. Nessas bases, a investigação de relações mantém a visão dicotômica, na qual as duas instâncias, embora comunicantes, mantêm-se independentes. Torna-se ainda evidente que, ao nos debruçarmos sobre o comportamento das audiências como suposta expressão da experiência do público, estamos nos voltando mais aos seus produtos e efeitos do que à experiência propriamente dita. O comportamento do público é tido como um conjunto de reações a determinados estímulos produzidos pelos dispositivos e o interesse mercadológico de tais pesquisas não parece esclarecer de modo satisfatório as motivações que lhe produzam. Se eles revelam alguma objetividade, sua análise é voltada para o controle do comportamento e do jogo de causalidade que o envolve. Porém, quando o objetivo é compreender a experiência como algo que está no centro da discussão sobre o espectador, pensar em 
termos de produtos e efeitos pouco nos revela sobre o que desejamos investigar, pois como nos mostra Depraz, Varela e Vermersch (2006), a experiência, considerada sob 0 aspecto de indicadores comportamentais, ou como produtos de sua atividade, não se configura como uma base relevante para a investigação neste campo. Consequentemente, não há nos estudos sobre recepção e nos discursos sobre o espectador, uma devida menção à dimensão concreta da experiência em sua gênese e tampouco uma proposta metodológica para sua investigação. Mesmo nas contribuições de teóricos como Stam (2000), considerado um autor contemporâneo marcadamente integrado à linha contextualista e tido como referência nesses estudos, ou ainda nas de Bordwel e Carow (1996) que investem numa perspectiva cognitiva e mais autônoma do espectador, o que percebemos é uma discussão em termos de ampliação das potencialidades do público. Trata-se de certa tomada de posição, onde os dispositivos são pensados como pertencentes ao processo histórico e suscetíveis às transformações engendradas no âmbito das relações que estabelecem entre si. Entretanto, tais discussões ainda partem sempre do ponto de vista das teorias e não da experiência concreta do público, mantendo-se uma visão dicotômica entre o mesmo e a obra. Bastaria afirmar teoricamente a condição de ser espectador, sem dar a devida atenção ao plano da experiência como instância instauradora dos próprios comportamentos?

Embora todos esses fatores estejam relacionados ao tema da espectatorialidade, não encontramos, nas teorias sobre o cinema, uma investigação sobre a especificidade dessa experiência, que possa nos servir para pensar a natureza da relação do espectador com o plano das imagens audiovisuais, fator este que somado a escassez sobre as pesquisas de recepção no cinema torna ainda mais importante o desenvolvimento de nossa investigação. Logo, os estudos sobre as audiências, embora revelem uma parte do problema, não são suficientes no sentido de dar conta deste. A pergunta a ser colocada é sobre como a natureza da experiência do expectador pode ser acessada e os estudos de Varela et al. (1991) e de Depraz et al. (2006) no campo das ciências cognitivas contemporâneas constituem um longo a caminho a ser posteriormente explorado, em busca de possíveis respostas. Neste momento, trazemos à cena o estudo de Jacques Rancière (2008) sobre o espectador emancipado.

\section{Sobre a emancipação do espectador}

A discussão sobre o espectador é bastante presente nos discursos sobre audiovisual. Todavia, o debate sobre a espectatorialidade não 
se restringe somente a esse âmbito específico, se expandindo a outras modalidades, como as artes plásticas, fotografia, etc. E é a partir desta inflexão que a obra de Jacques Rancière (2008), em especial "O Espectador Emancipado" traz uma grande contribuição a nossa investigação, uma vez que a noção de emancipação os aproxima de certo modo da discussão acerca da experiência espectatorial. O texto desenvolve uma reflexão sobre esse tema a partir do teatro, sendo a proposta do autor expandir o debate para o campo das artes em geral. Consideramos assim, que suas contribuições são pertinentes e aplicáveis a uma reflexão sobre a experiência do espectador no cinema.

Rancière (2008) retoma, em seu texto sobre o espectador emancipado, um problema discutido em sua obra anterior, O Mestre Ignorante (1987). Nele, o autor resgata o paradoxo de Jacotot ${ }^{3}$, que consiste no fato de o ignorante poder ensinar a outro ignorante aquilo que ele mesmo não sabe, promulgando a igualdade das inteligências e opondo a emancipação intelectual à instrução pública. Sua proposta é a de estabelecer uma reflexão entre a questão da emancipação e a do espectador na atualidade. Para tanto, remonta a uma discussão sobre arte e política a partir do teatro grego. É na trajetória desta discussão que Rancière (2008) retoma um paradoxo fundamental: o de que não há teatro sem espectador. A partir da leitura inicial que versa sobre o mal de ser espectador (no sentido de um suposto olhar contemplativo e contrário ao conhecer, e a passividade nele implícito), o texto tece considerações sobre o lugar de um "pathos" conferido ao teatro por Platão, que o considera como uma máquina óptica e de ignorância na formação de olhares na ilusão de passividade. "Ser espectador é estar separado ao mesmo tempo da capacidade de conhecer e do poder de agir" (Rancière, 2008, p. 8). Em seguida, o autor demonstra como os críticos da mimese teatral não se acomodaram neste lugar platônico, colocando o teatro como instrumento de ação, surgindo então a figura do drama como signo desse novo modelo. Nele, se desfaz a posição passiva e o olhar do público é submetido à relação dramática, no sentido da ação, tratando-se de um teatro sem espectadores. Esta colocação, a princípio contraditória, tem por objetivo assinalar a saída do estado de fascinação contemplativa, por um lado, e a perda do status de observador criterioso e da ilusão de controle por outro, sendo o espectador arrastado pelo circulo mágico da ação teatral. Os reformadores do teatro reformulam a posição platônica e fazem desta arte um corpo ativo de um povo, cuja função é pôr em ação seu princípio vital. Neste sentido, afirma-se o teatro como lugar de confronto do espectador consigo mesmo e com a coletividade, sendo esta uma fórmula coletiva exemplar. "O teatro é uma assembleia na qual as pessoas do povo tomam consciência de sua situação e discutem seus interesses" (Rancière, 2008, p. 11). 
Podemos deduzir, dessa primeira parte do texto de Rancière (2008), a proposição de uma concepção de espectatorialidade performativa, uma vez que "a cena e a performance teatrais (...) se propõem a ensinar a seus espectadores os meios de deixar de serem espectadores e tornarem-se agentes de uma prática coletiva" (Rancière, 2008, p. 13). Tal explanação introdutória tem a função de demarcar um posicionamento antigo, porém, vivo e ainda hoje atuante, no que concerne às práticas artísticas. A obra surge como instrumento de mediação, de revelação ao público supostamente ignorante, desta sua condição, sendo o mestre aquele que detém o saber (supostamente o artista), como detendo a chave e o poder de libertação as almas. Este princípio se manifesta no que o autor definiu como mediação evanescente entre o mal do espetáculo e a virtude do verdadeiro teatro. É neste ponto que o paradoxo da emancipação intelectual se torna relevante, pois a lógica pedagógica da mediação que comparece por excelência na obra teatral é, para o autor, um modo de subjugação política presente em todos os campos da arte, mantendo uma dissimetria fundamental no próprio processo de apropriação e na partilha dos discursos e das relações.

A noção de emancipação vem então a romper com esse paradigma. Trata-se efetivamente, no texto de Rancière (2008), de suplantar a perspectiva na qual a condição de perpetuação da mestria se dá pela manutenção da condição de ignorante por parte do aluno. Tal perspectiva é definida pelo autor como embrutecimento: “Ensina-Ihe primeiramente a sua própria incapacidade. Assim, em seu ato ele comprova incessantemente seu próprio pressuposto, a desigualdade das inteligências. Essa comprovação interminável é o que Jacotot chama de embrutecimento" (Rancière, 2008, p. 14).

$\mathrm{Na}$ lógica do embrutecimento, que podemos entender como sendo a lógica pedagógica tradicional, o ignorante não é somente aquele que ignora o que o mestre sabe. Ele é, para além desta afirmativa inicial, aquele que não sabe aquilo que ignora e os meios de como saber. Já o mestre não é somente aquele que detém o saber ignorado pelo ignorante, mas é aquele que sabe como torná-lo objeto de saber e aquele que sabe os meios que possui para isso. O que Rancière (2008), deseja evidenciar com seu argumento, por um lado, é a paradoxal condição de ignorância por parte das duas entidades, uma vez que a ignorância transcende o domínio daquilo que se sabe. Revelar o que se sabe é somente demonstração de exercício de poder por parte do mestre, através do fausto que constitui a própria demonstração. Esvazia-se assim a posição do mestre, pois o saber nunca dará conta do fato de sempre ignorarmos algo. Por outro lado, este é o eixo da discussão sobre a emancipação, pois "não há um ignorante que não saiba um monte de coisas, que não as tenha aprendido sozinho, olhando e ouvindo o que há ao seu redor, observando e repetindo, enganando-se e corrigindo seus erros" 
(Rancière, 2008, p. 14). Transpondo a perspectiva de um saber de ignorante comum a todos nós, e o saber da ignorância que faltaria na condição de aluno se tornar mestre (e que longe de superar a distância que separa o saber da ignorância como expressão de desigualdade, Ihe reafirma ainda mais), Rancière (2008), investe, não na manutenção desta situação relativa ao embrutecimento e a confirmação da desigualdade das inteligências, mas numa atitude de emancipação. Tal atitude é baseada no pressuposto da igualdade das inteligências, o que recoloca o problema da relação entre mestre e ignorante, assim como o do espectador com a obra artística. Neste sentido:

Não há dois tipos de inteligência separados por um abismo. (...) Desse ignorante que soletra signos ao intelectual que constrói hipóteses, o que está em ação é sempre a mesma inteligência que traduz signos em outros signos e procede por comparações e figuras para comunicar suas aventuras intelectuais e compreender o que outra inteligência se esforça por comunicar-lhe (Rancière, 2008, p. 15).

Trazendo o argumento para nossa discussão, trata-se da afirmação de uma autonomia peculiar a cada espectador, em se tratando da apropriação dos signos do mundo, independentemente da ordem de composição ou disposição deste último no plano da materialidade e das redes discursivas que o circundam. Isto é, não subordinada também a uma suposta ordem, hierarquia, classe ou lugar que o próprio espectador venha a ocupar no plano das relações sociais. E não podemos deixar de mencionar que ela remete à ordem de uma singularidade, que se caracteriza pela multiplicidade:

O poder comum aos espectadores, "é o poder que cada um tem de traduzir à sua maneira o que percebe, de relacionar isso com a aventura intelectual singular que o torna semelhante a qualquer outro, à medida que essa aventura não se assemelha a nenhuma outra" (Rancière, 2008, p. 20).

Consequentemente, a emancipação recoloca de modo geopolítico o problema do relacionamento dos sujeitos com o plano das imagens, uma vez que podemos considerá-lo como artífice daquilo que vê, sente e pensa. Neste movimento, o que se transpõe não é a distância como representante do abismo radical entre o mestre e o ignorante, tal como implícita na pedagogia do embrutecimento. Para Rancière (2008), ela não visa ser negada ou superada, mas se afirma como condição de toda comunicação.

O que havíamos anteriormente nos referido em nossa discussão sobre o ato de apropriação por parte do espectador, é descrito pelo 
autor como trabalho poético de tradução, entendido como capacidade de associar e dissociar a multiplicidade das imagens e dos discursos: "É nesse poder de associar e dissociar que reside a emancipação do espectador, ou seja, a emancipação de cada um de nós como espectador. Ser espectador não é condição passiva que deveríamos converter em atividade. É nossa condição normal" (Rancière, 2008, p. 21). A tradução se distingue de uma simples interpretação baseada em valores externos à experiência, tratando-se mais da colocação de um problema singular no âmbito de uma existência enquanto potência igualmente singular. Já não se trataria, por exemplo, de um problema proposto pelo dispositivo, visando à solução correta por parte do espectador (captar e entender sua proposta), ou de um problema estabelecido por alguém, como um enigma a ser decifrado. Trata-se de um problema, encarnado na experiência de cada um e que surge no modo único da sua relação com o dispositivo, independentemente (o que não significa que não possa ser solidário) de qualquer problema proposto por este último. Afirma-se assim, a partir das contribuições de Rancière (2008), o campo da experiência do espectador, onde a emancipação surge como expoente máximo de sua potencialidade.

A partir do que expomos sobre a emancipação, retomamos a discussão sobre a passividade do espectador. De certo modo, constatamos nos estudos sobre recepção e audiência anteriormente discutidos, a afirmação de uma visão mais aberta à experiência do público a partir da negação de um estado de passividade e a ele atribuído aprioristicamente. Porém, a passividade parece existir, nestes casos, como condição a ser ultrapassada ou como resultante de uma visão equivocada do ponto de vista teórico. Os discursos próatividade do espectador não encarnado no plano da experiência consideram que a atividade seria um estado a ser conquistado. Destacamos esses posicionamentos no intuito de pensar que a lógica do embrutecimento, tal como demonstrada por Rancière (2008), é geralmente mantida nestes casos, evidenciando-se, na verdade, uma relação segregatória entre os intelectuais e seus discursos e os espectadores supostamente ignorantes, nos quais o germe da atividade deve ser despertada. A atividade é tida neste caso, como signo de uma suposta valorização do espectador, tornando-se uma espécie de alegoria exibida como promessa de redenção e de mudança de paradigma por parte dos discursos teóricos. Porém, o que se verifica na prática é a manutenção do dispositivo como um instrumento construído a serviço de um suposto esclarecimento como chave de compreensão de uma realidade oculta ao espectador.

Dir-se-á que o artista, ao contrário, não quer instruir o espectador. Hoje ele se defende de usar a cena para impor uma lição ou transmitir uma mensagem. Quer apenas produzir uma 
forma de consciência, uma intensidade de sentimento, uma energia para a ação. Mas supõe sempre que o que será percebido, sentido, compreendido é o que ele pôs em sua dramaturgia ou em sua performance" (Rancière, 2001, p. 18).

Trata-se no mínimo de uma posição limitada, que sustenta o ponto de vista no qual o dispositivo teria por missão retirar o espectador de sua passividade, de sua inércia: "mesmo que não saibam o que querem que o espectador faça, o dramaturgo e o diretor de teatro sabem pelo menos uma coisa: sabem que ele deve fazer uma coisa, transpor o abismo que separa atividade de passividade" (Rancière, 2008 , p. 16). O autor afirma que esta dinâmica, além de manter a desigualdade entre as inteligências, desqualifica o espectador como agente de transformação da experiência. Cabe-Ihe somente neste caso, contemplar o fausto implícito na leitura da obra como demonstração de saber/poder por parte de outros que se afirmam como dignos e capazes da ação, mantendo assim, o espectador em sua posição submissa, embora contraditoriamente pretenda-se libertá-lo e insuflá-lo à ação. Entretanto, o autor questiona:

O que permite declarar inativo o espectador que está sentado em seu lugar, senão a oposição radical, previamente suposta, entre ativo e passivo? Por que identificar olhar e passividade, senão pelo pressuposto de que o olhar quer dizer comprazer-se com a imagem e com a aparência, ignorando a verdade que está por trás da imagem e a realidade fora do teatro? (Rancière, 2008, p. 16).

Rancière (2008) retoma sua crítica à passividade, realizando uma discussão sobre o olhar, na qual este é considerado como uma atividade fundamental. $O$ olhar, independentemente de ser contemplativo, nunca deixa de ser uma atividade. E sob esse ângulo o olhar é uma experiência. Ele tem uma função que vai muito além de simplesmente decodificar informação. Ele cria e compõe outras experiências. A emancipação considera que o espectador se coloca sempre no plano da atividade, mínima que seja, sendo esta inerente à própria ação de olhar:

A emancipação, por sua vez, começa quando se questiona a oposição entre o olhar e o agir, quando se compreende que as evidências que assim estruturam as relações do dizer, do ver e do fazer pertencem à estrutura de dominação e da sujeição. Começa quando se compreende que olhar é também uma ação que confirma ou que transforma essa distribuição de posições (Rancière, 2008, p. 17). 
Para Rancière (2008), é ilusória a oposição entre o olhar e a ação. O poder comum do espectador não decorre de sua qualidade de membro de um corpo coletivo ou de formas de interatividade dela decorrentes, mas do modo singular de seu olhar, da sua capacidade de leitura e apropriação do que ele percebe, num movimento incessante de produção/invenção de si e do mundo. Uma capacidade que, segundo o autor, torna cada um igual a qualquer outro e anula a dissimetria estabelecida no paradigma anterior. O que se evidencia no sistema tradicional de partilha dos signos por meio dos dispositivos é, na maioria das vezes, a manutenção de relações de poder e de dominação que situam os sujeitos na ordem dos discursos. É neste sentido, então, que a posição de Rancière (2008) nos permite pensar que 0 espectador interfere no plano das produções das imagens. Ele não estaciona no lugar que esperamos que ele ocupe, fazendo ao contrário, seu próprio percurso. Pois, como ressalta Rancière:

O espectador também age, tal como o aluno ou o intelectual. Ele observa, seleciona, compara, interpreta. Relaciona o que vê com muitas outras coisas que viu em outras cenas, em outros tipos de lugares. Compõe seu próprio poema com os elementos dos poemas que tem diante de si (Rancière, 2008, p. 17).

Portanto, o conceito de emancipação do espectador traz uma contribuição relevante para a compreensão das transformações no âmbito das relações dos espectadores com os dispositivos audiovisuais, enfatizando a atividade e os próprios movimentos do público.

\section{Conclusão}

As pesquisas de recepção e audiência abordam, do ponto de vista teórico, o problema da atividade do espectador, de modo limitado. Logo, os conceitos de recepção e de audiência não são suficientes para expressar esta ideia, mesmo no caso dos estudos culturalistas citados. Não devemos desconsiderar que estes últimos promovem um exercício valioso que atenta para o aspecto histórico e para o contexto como fatores cruciais nas relações entre o dispositivo audiovisual e o público. Porém, se limitam apenas a uma leitura tímida e aproximada do problema da experiência como base da atividade espectatorial.

O conceito de emancipação intelectual de Rancière (2008) surge como um caminho para ampliar o entendimento da relação dos espectadores com as imagens e repensar a espectatorialidade. A investigação sobre este tema, conduzida no domínio do dispositivo 
teatral, merece ser ampliada, embora seja conveniente investigar se existem especificidades inerentes a cada dispositivo e avaliar em que medida a pesquisa sobre a experiência espectatorial se realiza em cada um deles. É importante salientar que a emancipação é considerada um princípio e uma atitude fundamental do espectador. Ela nos aponta que existe um modo específico de experiência e de relação dos sujeitos com o plano das imagens cinematográficas.

Ressaltamos que a emancipação não se reduz a um regime de traduções de cunho individual, mas possui uma dimensão coletiva. Ela possibilita um intercâmbio de múltiplas forças que perpassam os dispositivos, os espectadores, os discursos e as políticas de produção e circulação das obras. A dimensão de coletividade não diz respeito a corpos passivos e assujeitados, que devem ser mobilizados para ação através do dispositivo, seja ele teatral ou audiovisual, tal como no paradigma do embrutecimento. Rancière (2008) se refere a um poder comum, num sentido de intercâmbio entre inteligências, afirmando que suas características se revelariam, a princípio, como parte de uma atividade intelectual por excelência. $O$ poder comum da igualdade das inteligências liga indivíduos, faz que eles intercambiem suas aventuras intelectuais e, ao mesmo tempo, se posicionem uns em relação aos outros de modo distinto. O espectador é capaz de utilizar esse poder comum a todos para traçar seu caminho próprio e singular. Em função deste fato, nossa discussão busca revisitar o conceito de espectatorialidade a partir da perspectiva da emancipação. No campo do audiovisual, sugerimos a inflexão da noção de emancipação intelectual em prol de uma emancipação espectatorial. E o princípio fundamental desta emancipação é justamente essa especificidade inerente ao espectador, que se apropriaria de modo singular dos materiais audiovisuais, produzindo suas traduções a partir de suas próprias referências, construídas coletivamente.

A experiência espectatorial se oferece como um campo propício a futuras investigações. A nosso ver, o foco dessa experiência deve ser justamente a sua especificidade emancipatória, caracterizada também pela atividade intelectiva. O espectador utiliza seus recursos num amplo e contínuo trabalho de tradução, analisando, selecionando e comparando à sua maneira, signos de toda ordem e natureza. Como afirma Rancière (2008), reconhecer esses signos é empenharse em certa leitura de nosso mundo. Neste momento, buscamos preparar o terreno teórico que resta aberto, para o desenvolvimento futuro de pesquisas empíricas. Consideramos que a participação de fatores perceptivos e cognitivos nos processos espectatoriais oferece oportunidade de ampliação da dimensão da experiência do espectador, incluindo-se nela outros fatores. No presente estudo, o esforço de delimitação do problema da experiência espectatorial lança o desafio de investigar como se desenrolam concretamente esses 
processos. E devemos considerar que experiência espectatorial é, numa perspectiva ativa e emancipada, marcada também por um regime de afetabilidade. A questão de como tal regime de afetabilidade comparece no trabalho de tradução é algo a ser aprofundado. Como nos mostra Rancière (2008), trata-se de afetos que embaralham as falsas evidências dos esquemas intelectivos estratégicos. São disposições do corpo e do espírito nas quais o olho não sabe de antemão o que está vendo e o pensamento não sabe o que fazer com aquilo.

É importante atentar para o problema do quanto o dispositivo audiovisual condiciona a experiência espectatorial e de que modo pode contribuir para ampliá-la e refiná-la. Longe de pensarmos em termos de uma relação dicotômica entre o dispositivo audiovisual e o espectador, percebemos que ambos compõem um regime de afetabilidade mútua, no qual, tanto o espectador quanto o meio audiovisual se encontram em constante processo de troca, de ativação recíproca e de transformação. Neste sentido, reafirmamos a posição de Stam, (2000) segundo a qual o dispositivo e o espectador se reinventam reciprocamente. Porém, entendemos que a noção de reinvenção ganha nova força quando o plano da experiência audiovisual passa a ser pensado como composto de múltiplas forças, não sendo simplesmente determinado pelos discursos técnicos, críticos e políticos sobre os dispositivos.

Para finalizar, é preciso reconhecer que existem tensões e hiatos entre a concepção do dispositivo audiovisual como instrumento didático de uma revelação, os discursos que o circundam e o plano da experiência espectatorial em sua especificidade emancipatória. Nesse plano de tensões equacionam-se, tanto a obra cinematográfica e as concepções do artista que a idealizou, quanto as percepções, os afetos e os saberes oriundos da experiência do espectador. De acordo com Rancière (2008), o dispositivo não é um produto exclusivo do artista. Ele se desprende deste último na medida em que é apropriado pelo público. Da mesma forma, ele se desprende também do espectador, pois no ato de apropriação, a especificidade daquilo que foi apropriado se perde, constituindo-se já outra coisa, cuja propriedade já não pode ser reivindicada por nenhum deles. Para o autor, o dispositivo é uma terceira coisa, sem proprietários. Seu sentido não pode ser localizado, afastando, por exemplo, qualquer pressuposição de transmissão fiel de uma ideia ou conteúdo por parte do artista para o público, através da obra, segundo uma visão simplista de causa e efeito. Portanto, a pesquisa sobre a espectatorialidade não deve voltar-se somente a uma discussão sobre a ação dos dispositivos ou sobre aspectos relativos ao processo de edição, tais como fatores tecnológicos e suas incidências sobre o público, por exemplo. Certamente esses elementos não devem ser ignorados. Todavia, a partir da perspectiva da emancipação, tais 
fatores técnicos das obras deixam de ser o foco principal, priorizandose agora a experiência do espectador, em seu movimento emancipatório e em seu trabalho de tradução, destacando-se a função cognitiva na construção das relações com a multiplicidade de imagens.

\section{Referências}

Barthes, R. (1964). Elementos de Semiologia. São Paulo: Cultrix.

Bordwell, D., \& Carrow, N. (1996). Post-Theory: Reconstructing Film Studies. Madison: University of Wisconsin Press.

Bretch, B. (1964). Estudos Sobre Teatro. Rio de Janeiro: Nova Fronteira.

Depraz, N., Varela, F., \& Vermersch, P. (2006). La réduction à l'épreuve de l'expérience. Arquivos Brasileiros de Psicologia, 58(1), 75-86.

Escotesguy, A. C., \& Jacks, N. (2005). Comunicação e Recepção. São Paulo: Hacker Editores.

Escotesguy, A. C. (2006). Estudos Culturais: as Margens de um Programa de Pesquisa. ECOMPÓS. Revista da Associação Nacional dos Programas de Pós-Graduação em Comunicação, 06(2), 01-16.

Gomes, R. (2005). Teorias da Recepção, História e Interpretação de Filmes: Um Breve Panorama. In Anais do IV Congresso da Sociedade Portuguesa de Comunicação - SOPCOM, Aveiro, Portugal.

Jacks, N. (2008). Meios e Audiências. A Emergência dos Estudos de Recepção no Brasil. Porto Alegre: Editora Sulina.

Jacks, N. (2014). Meios e Audiências II. A Consolidação dos Estudos de Recepção no Brasil. Porto Alegre: Editora Sulina.

Mascarello, F. (2004). Os Estudos Culturais e a Espectatorialidade Cinematográfica: Um Mapeamento Crítico. Revista ECO-PÓS, 07(2), 92-110.

Mascarello, F. (2001). A Screen-Theory e o Espectador Cinematográfico: Um Panorama Crítico. Revista Novos Olhares, 08(2), 13-28.

Metz, C. (1980). Linguagem e Cinema. São Paulo: Editora Perspectiva, 1980.

Orozco, G. (2001). Televisión, Audiencias y Educación. Colombia: Grupo Editorial Norma.

Rancière, J. (1987). O Mestre Ignorante. Cinco Lições Sobre a Emancipação Intelectual. Belo Horizonte: Autêntica.

Rancière, J. (2008). O Espectador Emancipado. Rio de Janeiro: Martins Fontes. 
Stam, R. (2000). Introdução à Teoria de Cinema. São Paulo: Editora Papirus.

Turner, G. (2000). Cultural Studies and Film. In: Hill, J., \& Gibson, P. C. (Eds.). Film Studies: Critical Approaches, (pp.193-199). Oxford: Oxford University Press.

Varela, F., Thompson, E., \& Rosch, E. (1991). A Mente Corpórea. Ciência Cognitiva e Experiência. Lisboa: Instituto Piaget.

\section{Endereço eletrônico \\ Fabio Montalvão Soares}

Universidade Federal do Rio de J aneiro

Programa de Pós-Graduação em Psicologia, Instituto de Psicologia da UFRJ

Av. Pasteur, 250 fundos, Praia Vermelha, CEP 22290-902, Rio de Janeiro-RJ, Brasil

Endereço eletrônico: fabio.montalvao@ufrj.br

\section{Virgínia Kastrup}

Universidade Federal do Rio de Janeiro

Programa de Pós-Graduação em Psicologia, Instituto de Psicologia da UFRJ

Av. Pasteur, 250 fundos, Praia Vermelha, CEP 22290-902, Rio de Janeiro-RJ, Brasil

Endereço eletrônico: virginia.kastrup@gmail.com

Recebido em: 08/03/2015

Reformulado em: 19/08/2015

Aceito para publicação em: 20/08/2015

\section{Notas}

* Doutorando em psicologia pela Universidade Federal do Rio de Janeiro - UFRJ; Rio de Janeiro, Brasil.

** Doutora em psicologia clínica pela Pontifícia Universidade Católica de São Paulo; pós doutora em ciências da cognição no Centre National de la Recherche Scientifique (Paris), e em psicologia cognitiva da deficiência visual no Conservatoire National des Arts et Metiers (Paris); professora associada na Universidade Federal do Rio de Janeiro.

1 Segundo o autor, o modernismo político se caracteriza pelo amalgamento estruturalista/ pós-estruturalista entre a semiologia "metziana", a psicanálise lacaniana e o marxismo althusseriano, incluindo as teorias francesas da desconstrução e do dispositivo (pós-maio de 1968, nas revistas Cinéthique e Cahiers du Cinéma) e a teorização anglo-americana liderada pelo periódico inglês "Screen". Cf.: Fernando Mascarello (2004). Os Estudos Culturais e a Espectatorialidade Cinematográfica: Um Mapeamento Crítico. Revista ECO-PÓS, 07(2), p. 92.

${ }^{2}$ A Screen-Theory é um movimento constituído a partir da reunião de um conjunto de intelectuais em torno da revista inglesa "Screen", que posteriormente ganhou destaque no cenário americano. A revista se caracterizava como um corpus alternativo às publicações correntes de origem francesa, tais como a Cinéthique e o Cahiers du Cinéma. Cf.: Conferir: Fernando Mascarello (2001). A Screen-Theory e o Espectador Cinematográfico: Um Panorama Crítico. Revista Novos Olhares, 08(2), p. 24.

${ }^{3}$ J oseph Jacotot é um pedagogo francês que viveu no século XIX, reconhecido por sua posição crítica em relação aos projetos educacionais inspirados no cientificismo e no ideal de progresso comuns em sua época. Rancière se apropria de sua obra a fim de salientar o conceito de emancipação intelectual em oposição ao que o pedagogo denominava como embrutecimento. Sobre o assunto cita: "Era bem isto que Jacotot tinha em mente: a maneira pela qual a Escola e a sociedade 
infinitamente se simbolizavam uma à outra, reproduzindo assim, indefinidamente o pressuposto desigualitário em sua própria denegação" (Rancière, 1987, p. 15). Posteriormente, Rancière definirá, em sua obra de 2008, a emancipação intelectual como um princípio fundamental no desenvolvimento de suas teorias sobre o espectador. 